IZA DP No. 7525

New Directions for Residential Mobility Research:

Linking Lives through Time and Space

Rory Coulter

Maarten van Ham

Allan Findlay

July 2013 


\title{
New Directions for Residential Mobility Research: Linking Lives through Time and Space
}

\author{
Rory Coulter \\ University of Cambridge \\ Maarten van Ham \\ Delft University of Technology and IZA \\ Allan Findlay \\ University of St Andrews
}

Discussion Paper No. 7525

July 2013

IZA
P.O. Box 7240
53072 Bonn
Germany

Phone: +49-228-3894-0

Fax: +49-228-3894-180

E-mail: iza@iza.org

\begin{abstract}
Any opinions expressed here are those of the author(s) and not those of IZA. Research published in this series may include views on policy, but the institute itself takes no institutional policy positions. The IZA research network is committed to the IZA Guiding Principles of Research Integrity.

The Institute for the Study of Labor (IZA) in Bonn is a local and virtual international research center and a place of communication between science, politics and business. IZA is an independent nonprofit organization supported by Deutsche Post Foundation. The center is associated with the University of Bonn and offers a stimulating research environment through its international network, workshops and conferences, data service, project support, research visits and doctoral program. IZA engages in (i) original and internationally competitive research in all fields of labor economics, (ii) development of policy concepts, and (iii) dissemination of research results and concepts to the interested public.
\end{abstract}

IZA Discussion Papers often represent preliminary work and are circulated to encourage discussion. Citation of such a paper should account for its provisional character. A revised version may be available directly from the author. 
IZA Discussion Paper No. 7525

July 2013

\section{ABSTRACT}

\section{New Directions for Residential Mobility Research: Linking Lives through Time and Space}

While researchers are increasingly reconceptualising international migration, less interest is being shown in rethinking the geographies of short-distance residential mobility and immobility. Short-distance moves are crucial for the structuration of everyday life, the operation of housing and labour markets and the (re)production of social inequalities. This paper argues that a deeper understanding of residential mobility and immobility can be gained by exploring developments in longitudinal analysis while seeking theoretical innovations derived from extending life course theories. Rethinking the geographies of residential mobility around notions of 'linked lives' will allow us to understand, critique and address major contemporary challenges.

JEL Classification: J61, R23

Keywords: biography, life course, linked lives, longitudinal analysis, relationality, residential mobility

Corresponding author:

Rory Coulter

Department of Sociology

University of Cambridge

Free School Lane

Cambridge, CB2 3RQ

United Kingdom

E-mail: rcc46@cam.ac.uk 


\section{Introduction}

The last two decades have witnessed an explosion of interest in the geographies of population mobility (Smith and King, 2012). Much of this attention has been directed towards (re)theorising and analysing processes of long-distance international migration (Ellis, 2012). While this literature is yielding important insights and taking human geography in exciting new directions, in this paper we argue that geographical scholarship can be enriched by reconsidering the neglected geographies of shortdistance residential mobility and immobility (Cooke, 2011; Ellis, 2012).

There are a number of reasons why these geographies are important. As most people move rarely and generally over short distances (Ellis, 2012; Hanson, 2005), local moves and immobile spells have huge significance for the structuration of everyday lives of production and reproduction. In addition, local moves and residential immobility affect the operation of housing and labour markets (Battu et al., 2005; Coulson and Fisher, 2009). Residential mobility and immobility also (re)produce spatiotemporal inequalities through diverse processes such as segregation, gentrification and the intergenerational transmission of wealth (Clark and Ledwith, 2006; Friedman, 2011; Mulder, 2007). Hence, grappling with contemporary issues such as rising inequalities and population ageing requires rethinking the geography of residential mobility (Bailey and Livingston, 2007; Evandrou et al., 2010).

Over the last twenty-five years, geographical analysis of residential mobility has been transformed by situating residential relocations within the theoretical framework of the life course (Clark and Davies Withers, 2007; Geist and McManus, 2008). Drawing on life course theories has enabled geographers to make great strides in understanding why, when and where people move (Clark, 2008; Cooke 2008). For instance, Bailey's (2009) recent review demonstrates how research is exploring the ways in which residential moves are interwoven with household, employment, housing and health trajectories (Mulder, 2007).

One of the most valuable features of the life course approach is that it guides us to link residential mobility to the wider structuration of society (Halfacree and Boyle, 1993; Healey, 2006). By conceptualising residential mobility as recursively linking the actions of individuals to the (re)production of spatio-temporal structures (Bailey, 2009), life course theories emphasise that residential mobility acts as an 'engine of structuration' ${ }^{1}$ across a range of spaces and scales. This recursive interplay of people and places through residential mobility is never divorced from power relations (Bailey, 2009). For example, while residential moves configure and are affected by the socioeconomic and ethnic micro-geographies of neighbourhoods (Clark, 2008), gendered family migration processes are linked to the broader (re)production of patriarchy (Halfacree, 1995; Smith, 2004). Similarly, residential mobility is implicated in the structuration of virtual space. Exercising agency online (for instance via locational tagging or internet shopping) generates spatially-referenced traces, allowing corporate structures to configure the online environment and influence behaviour via targeted advertising. Mobility is not only implicated in the (re)production of power imbalances between individuals (Abraham et al., 2010), it is also embedded within power geometries stretching across spatio-temporal structures such as welfare regimes or housing and labour markets (Sharkey, 2012).

This paper argues that a deeper understanding of these processes can be gained through operationalizing and extending the concept of 'linked lives' developed in life 
course research (Bailey et al., 2004; Mayer, 2009). By highlighting that the life of an individual cannot be understood without considering the lives of others they are linked to across space-time (for instance family members or friends), the life course perspective (together with literature on transnational households (Blunt, 2007; Mitchell, 2004; Yeoh et al., 2005)) emphasises the relationality of residential mobility and immobility behaviour. Insights from life course theories and family sociology suggest that residential mobility and immobility are also biographical processes embedded within long-term life trajectories configured by period and cohort effects (Feijten, 2005; Smart, 2011).

Conceptualising mobility as a recursive, power-laden and relational process points social scientists in exciting new directions (Bailey, 2009). Methodologically, probing issues of synchronicity, relationality and spatio-temporal contingency requires longitudinal analysis (De Groot, 2011; Mulder and Malmberg, 2011). Following people across long periods of time offers a unique way to investigate how processes, outcomes and performances of mobility unfold over life courses (Graham et al., 2011; Mulder, 2007). Although data constraints meant that empirical research in this area traditionally lagged behind theory, these restrictions are quickly evaporating. The rapid proliferation of rich longitudinal datasets allied with methodological developments is enabling residential mobility research to be driven in new directions by the synergies between theoretical advances, analytical innovations and contextual change.

This paper begins by arguing for renewed interest in short-distance moves and residential immobility. Next, the paper outlines the conceptual value of the life course approach, showing how issues of relationality and biography are becoming key concepts in our understanding of residential mobility and immobility. The paper then explores how the interface of contextual changes, theoretical advancement and data developments are taking residential mobility research in multiple new directions. In the penultimate section, the paper contends that incorporating a greater sensitivity to uneven power relations into this emerging agenda will allow researchers to contribute to understanding, critiquing and addressing contemporary problems. The paper then concludes with some reflections about the broader implications of rethinking the geographies of residential mobility and immobility.

\section{Residential mobility in a mobile world}

Social scientists are fascinated by movements. Over the last decade, this fascination has produced an outpouring of work loosely organised into what Sheller and Urry (2006) term the new mobilities paradigm (Cresswell, 2011; 2012). This 'mobilities turn' casts movement as an ontological category providing structure to the contemporary world (Cresswell, 2011). Given the rich tradition of geographical research into heterogeneous forms of mobility, it is perhaps unsurprising that geographers have been active participants in this emerging mobilities literature (Adey, 2010; Holdsworth, 2013).

Despite burgeoning interest in how practices and cultures of movement define the contemporary world, King (2012) argues that researchers must not neglect migration and residential mobility. King argues that these embodied movements remain of crucial significance for people's everyday lives, life course biographies and senses of identity (Mason, 2004; Winstanley et al., 2002). Perhaps uniquely among the social sciences, geographers have long been interested in these corporeal movements and this strand of 
research continues unabated (Dennett and Stillwell, 2010; Fielding, 2012; Plane and Jurjevich, 2009). Nonetheless, over the last thirty years the focus of geographical research in this area has shifted. As 'migration' has become increasingly synonymous with long-distance and international moves, studies of international migration have proliferated and eclipsed research into shorter distance residential mobility (Ellis, 2012). This focus on international moves may be due to globalisation and the increasing size and visibility of migration flows (King, 2012), although it could also be driven by the political potency of immigration issues in Western countries (Ellis, 2012).

To investigate scholarly trends in population mobility research, Figure 1 presents the results of citation analyses exploring temporal trends in the frequency of cites to the terms "residential mobility", "international migration" and "transnational" with "migration". The figure shows the number of publications per five-year period returned by electronic searches keyed on these terms. To ensure that any patterns found are robust, each graphic presents the results from searches of a different system made using slightly different criteria.

The picture painted by Figure 1 is remarkably consistent. While the absolute number of citations to "residential mobility" has risen considerably over the last thirty years, cites to "international migration" have increased much more markedly (particularly since 2000). This has occurred at the same time as issues of transnationalism have come to the fore in migration research (Carling, 2007; Carling et al., 2012). Overall, it seems that scholarly interest in international migration is developing at a much faster rate than the analysis of shorter distance relocations. Moreover, research on international migration has been infused with new conceptualisations of the nature and meaning of movement (King, 2012), while fewer attempts have been made to retheorise internal migration and residential mobility.

There are a number of reasons why geographers need to address this relative neglect of local moves and residential immobility. Firstly, although the absolute size of international migration flows has undoubtedly grown over the last few decades, international moves still remain far less common than moves within a single country (Ellis, 2012). Within countries, shorter distance moves are also the norm. In Britain, over $50 \%$ of the residential moves made in the year preceding the 2001 Census took individuals fewer than 5km (Bailey and Livingston, 2007: 15). The predominance of short distance moves is also evident in much larger countries like the US or Australia (Clark and Maas, 2012). Even today, many people never move away from the area in which they were born or grew up. Understanding how people relocate to adapt to changes in their linked life courses therefore requires analysis of the large volume of moves made over comparatively short distances (Clark and Huang, 2004).

Research shows that residential moves are also fairly rare events in most people's lives (Fischer and Malmberg, 2001; Hanson, 2005). Residential immobility is therefore an important factor for the structuration of societies. This immobility is not necessarily the product of 'choice', but can occur because structural processes such as tight housing markets impede people from fulfilling their moving desires (Coulter and van Ham, 2013; Rabe, 2012). Conceptualising how people navigate the opportunities and constraints imposed by macro-structures therefore requires considering why people do not move even though they may want to. Such work is particularly important for understanding the economic geography of housing and labour markets, which are generally thought to operate most efficiently when people can be spatially flexible (Battu et al., 2005; Coulson and Fisher, 2009). 
Figure 1. The number of documents by year of publication returned by electronic database searches for (1) "residential mobility”, (2) "international migration", and (3) "transnational” with "migration"
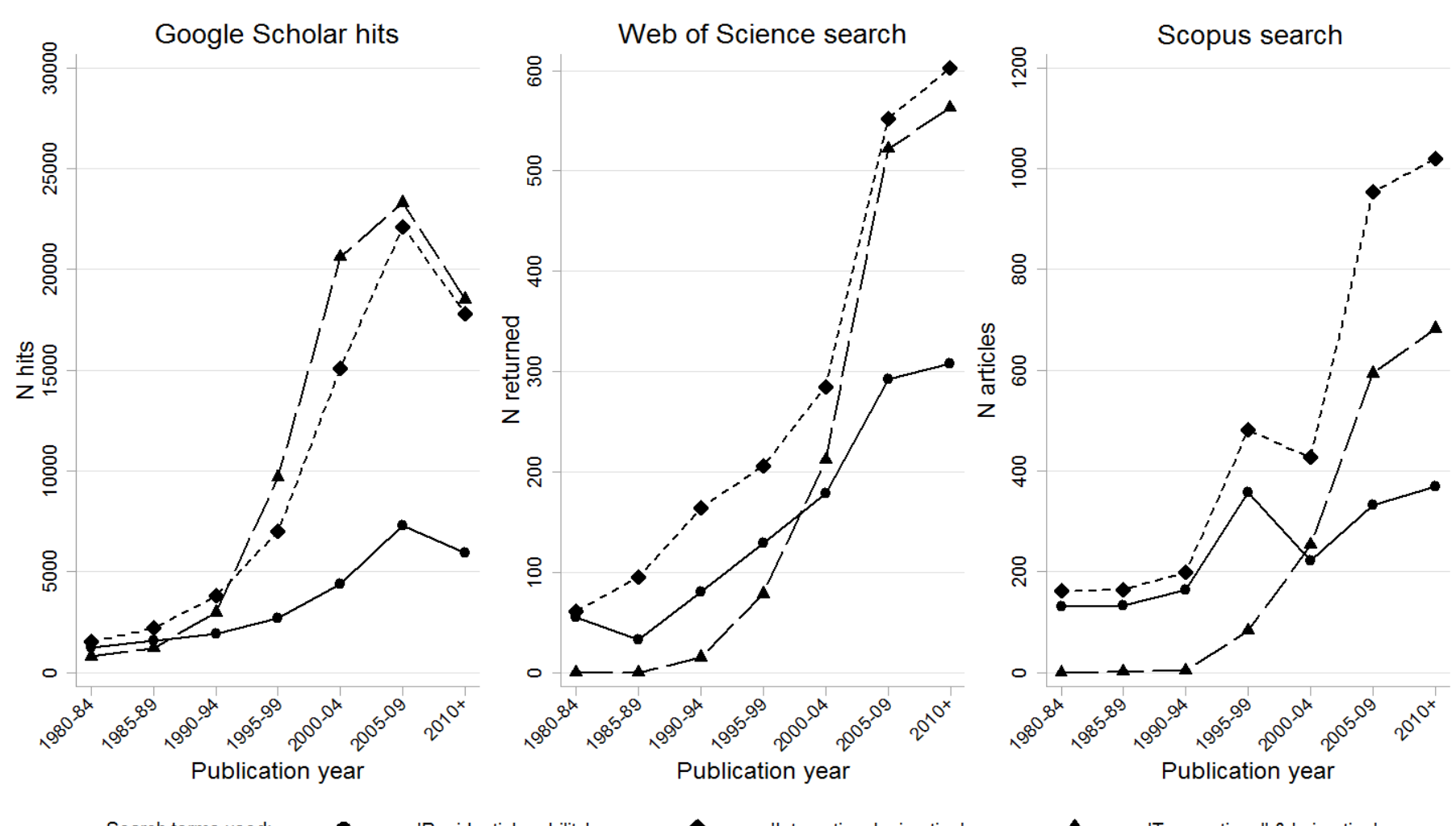

Notes: Searches were conducted on 18/04/2013. Google Scholar hits are defined as documents (excluding citations and patents) containing the search terms anywhere in the text. The Web of Science ${ }^{\circledR}$ topic search was conducted using the Social Science Citation Index ${ }^{\circledR}$ database. The Scopus search was conducted on the title, abstract and keywords of all articles and reviews indexed in the Scopus Social Science and Humanities database. 
Analysing short distance moves and residential immobility is crucial for understanding the (re)production of spatial inequalities. It has been well-documented that selective residential mobility patterns help to produce socio-economically polarised neighbourhoods (Hedman et al., 2011; Sharkey, 2012). Similarly, studies of segregation, gentrification and studentification all emphasise how the population composition of neighbourhoods is configured by mobility patterns (Hedin et al., 2012; Simpson and Finney, 2009; Smith, 2008). While Smith (2011) discusses how selective flows of long-distance migrants can produce family-absent and family-dominated neighbourhoods, understanding these types of neighbourhood change clearly also requires considering the much larger proportion of moves that occur over short distances.

Finally, analysing the social reproduction of inequalities requires consideration of local moves and residential immobility. Questions surrounding the intergenerational transmission of (dis)advantage often hinge upon how people accumulate housing wealth over their lifetime before passing this on to their descendants (Helderman and Mulder, 2007; Mulder, 2007). Contemporary and historic inequalities in housing can therefore cast long shadows across subsequent generations, for instance as the children of renters are unable to receive the financial assistance available to people with parents who own their own home (Kurz, 2004). This is becoming evident in Britain, as entry into homeownership is increasingly postponed and restricted to young adults who can draw upon family resources (Heath and Calvert, 2013). If welfare retreat makes people increasingly reliant on family support networks (Bell and Rutherford, 2013), current inequalities in the distribution of wealth will have long-lasting impacts on people's future life course biographies (Hillmert, 2013). Understanding residential mobility and immobility is therefore a well-signposted but important new direction for geographers seeking to understand and critique the structuration of contemporary societies.

\section{Residential mobility from a life course perspective}

A deep engagement with the life course perspective provides a useful framework for developing a revitalised residential mobility research agenda which can grapple with new contexts, data and methods. While recent reviews highlight the value of the life course approach (Bailey, 2009; Mayer, 2009), three key aspects of life course theories make them especially valuable for rethinking residential mobility when "all the world seems to be on the move" (Sheller and Urry, 2006: 207). Firstly, life course theories allow us to conceptualise the diversity of life trajectories without losing sight of how these are configured by structural forces operating across space-time (Elder, 1994; Mayer, 2009). By positing that people follow their own household, employment, education, housing and health 'career' pathways (Mulder and Hooimeijer, 1999), the life course perspective takes us beyond deterministic notions of a shared life cycle (Warnes, 1992). This guides us to conceptualise mobility as neither an exclusively economic nor demographic process (Halfacree, 2004; Geist and McManus, 2008). This focus on diversity in the occurrence, timing and sequencing of life events fits well with contemporary contextual realities (Feijten, 2005), such as reduced job security and increasingly complex family forms (Geist and McManus, 2008; Mulder, 2007).

Life course theories also propose that life courses are bound together by relational ties (Bailey, 2009; Elder, 1994). In this perspective, the life of an individual 
cannot be disentangled from the lives of other people they are connected to through kinship bonds or social ties. By emphasising how people are linked together through space-time, the life course approach suggests that moving decisions and mobility behaviours are fundamentally relational (Bailey et al., 2004; Mason, 2004). For many people, ties within the household unit and bonds to wider social and kin networks exert particularly strong influences on their residential mobility behaviour (Mulder, 2007). These links between relational ties and mobility are fundamentally recursive, as moving simultaneously affects a person's interactions with others (Smart, 2011).

The final insight provided by the life course approach comes from viewing lives as biographies (Dykstra and van Wissen, 1999). The biographical metaphor suggests that events and transitions in the life course are given meaning by the longer-term trajectory within which they are situated (Elder, 1994; Smart, 2011). While this initially suggests a rather individualised understanding of time, life course theories also argue that personal biographies are collectively configured by spatio-temporal processes (Feijten, 2005). These collective impacts are often conceptualised as period effects (Mayer, 2009). As individuals born at a similar time live out their lives under a shared set of structural conditions, the notion of cohort-specific commonalities of experience is also a powerful component of the life course approach (Elder, 1994). For mobility research, this emphasis on biographies and the multidimensional nature of time guides us to conceptualise moving as a process rooted in the context of past experiences, as well as hopes and aspirations for the future (Gutting, 1996; Kley and Mulder, 2010).

By drawing our attention to how lives are relationally and biographically interwoven through space-time, life course theories provide a useful framework for understanding how mobility is a mechanism through which agents and structures recursively interact. Thus, life course analyses of residential mobility direct us away from conceptualising people as either decontextualized actors or the pawns of structural forces (Halfacree, 2004; Mason, 2004; Scott, 1997). Although mobility researchers have long invoked life course theories (Clark and Huang, 2003; Warnes, 1992), studies are only now beginning to rigorously apply the core insights of the life course perspective to explore how residential mobility and immobility are configured by people's linked lives.

\section{III.1 Relationally linked lives}

Family sociologists and human geographers are increasingly conceptualising people as reflexive actors linked by relationships (Bailey, 2009; Smart, 2011). Harnessing these insights, mobility researchers are probing how relationality impacts on mobility behaviour across the individual and household scales. Migration research has been at the forefront of analysing how lives are linked together within households. While human capital and gendered migration theories vie to explain why women's labour force careers are often inhibited by family migration (Cooke, 2008; Geist and McManus, 2012; Smith, 2004), both perspectives agree that the moving behaviour of couples cannot be understood without considering the linked life courses of both partners. This conclusion is supported by qualitative analyses showing how couples make migration decisions through bargaining and negotiation (Bailey et al., 2004; Seavers, 1999). Recent studies have extended this perspective to also explore how the agency of children influences family migration decisions (Bushin, 2009). 
In contrast, residential mobility research has traditionally conceptualised households as unified social actors. Many of the classic models of residential mobility decision-making adopted a behavioural perspective, conceptualising moving decisions in terms of an individualised cognitive process which could be 'scaled up' to the household level (Brown and Moore, 1970; Rossi, 1955; Speare et al., 1975). This assumption that household decision-making can be conceptualised as a cognitive process continues to influence contemporary studies (Diaz-Serrano and Stoyanova, 2010; Kley, 2011).

A growing literature is critiquing this individualised perspective on residential mobility by emphasising the need to consider how lives are intertwined within households. Recent work demonstrates that considering the moving desires of both partners in a couple is important for modelling household relocation (Coulter et al., 2012; Ferreira and Taylor, 2009). Developing a longitudinal linked lives approach has enabled Rabe and Taylor (2010) to show how neighbourhood outcomes are influenced by the subjective neighbourhood evaluations of both partners in couples. This implies that studying how short-distance moving decisions are relationally configured can help us to understand how differing needs and perceptions within households can have geographical consequences, for example for neighbourhood composition. There are clear links to be built here with migration research, which has a distinguished tradition of linking moving decisions to the power asymmetries generated by gendered ideologies and labour market structures (Cooke, 2008).

Following Mulder (2007) and a 2009 special issue of Population, Space and Place (Mulder and Cooke, 2009), a second strand of linked lives research is now investigating how moving behaviour is configured by geographically dispersed social and kin networks (Blaauboer et al., 2013). This is becoming an important issue across the Western world as ageing populations and welfare retrenchment combine to increase the volume of resources, care and support which are exchanged through personal networks (Bell and Rutherford, 2013; Mulder, 2007).

Extended social and family networks may affect the propensity for people to move, as well as their residential choices when they do relocate (Lundholm 2012). For example, Belot and Ermisch (2009) show that dense local friendship networks deter residential moves. Analyses of Dutch and Swedish population registers have shown that moving is also affected by kinship geographies (Michielin et al., 2008; Pettersson and Malmberg, 2009). As these latter studies draw on administrative data, they can however tell us relatively little about how the qualitative nature of relationships affects mobility. As Michielin et al. (2008) point out, adults may move closer to their parents because they have emotional or social ties to where they grew up, rather than because they want greater contact with their parents (Blaauboer, 2011). This qualitative dimension of linked lives is an issue requiring greater attention, particularly given that technological changes are facilitating modes of social interaction which rely less on geographical proximity.

The geography of extended networks may have particularly strong impacts on mobility behaviour at specific 'flashpoints' over the life course. Much research in this area has focused on how care needs in later life configure mobility, often by exploring the spatial mobility of adult children and their elderly parents (Hedman, 2013; Lundholm and Malmberg, 2010; Pettersson and Malmberg, 2009). Less is known about how relational links affect moving behaviour earlier in the life course, in particular 
around the increasingly drawn out, reversible and 'fuzzy' transition out of the parental home (Berrington and Stone, 2009; Stone et al., 2011; Sage et al, 2013).

This emerging literature on linked lives raises broader questions about how demographic trends are reshaping mobility by creating more complex family networks. Trends towards higher rates of separation and divorce are promoting new forms of constrained mobility (Feijten and van Ham, 2013; Gram-Hanssen and Bech-Danielsen, 2008; Mulder and Malmberg, 2011), while the growth in reconstituted families means separate households are increasingly bound together through the joint custody of children (Mulder and Wagner, 2010). These examples suggest that scholars need to question the tacit assumption that networks act as enabling resources, since kinship ties can also restrict a person's freedom to act in particular ways. On a more conceptual level, exploring how distinctive cohorts exhibit different moving behaviours through time would allow geographers to recursively link mobility trends to new spatial patterns of living and working (Kulu and Boyle, 2010).

\section{III.2 Linking lives through space-time: Renewing the call for a biographical approach}

In a landmark paper in Progress in Human Geography, Halfacree and Boyle (1993) argued that a biographical turn in mobility research could harness developments in social theory to enrich how mobility was theorised and studied. Although scholars quickly took up this challenge by conducting autobiographical studies of transnational mobility (Findlay and Li, 1997), researchers have only recently begun to situate their analyses of residential mobility within the context of biographical trajectories (Coulter and van Ham, 2013). Given that this approach requires tracking people over time, it is perhaps unsurprising that most of the biographical literature has drawn on retrospectively gathered ${ }^{2}$ qualitative data. In keeping with McHugh's (2000) plea for ethnographic methods, several researchers have conducted qualitative analyses of individuals' residential and geographical histories (Clark, 2009; Mason, 2004). These have shown how individuals' ties to people and places evolve over time and are used in identity construction and projection (Winstanley et al., 2002).

While retrospective analyses are valuable, this approach can only take us a little way towards understanding how linked lives configure mobility behaviour and hence act as 'engines of structuration'. Even setting aside thorny issues of recall bias and the contextual conditioning of responses (Schwartz, 2012), questions linking the subjective dimension of biographies to mobility behaviour simply cannot be answered using retrospective techniques. This is because it is very difficult for people to report the opinions, feelings or attitudes that they held in the past. There are also philosophical implications arising from a reliance on retrospective data. While the life course perspective guides us to explore how lives unfold over time, gathering retrospective data inevitably means that the past is to some extent filtered, interpreted and narrated through the lens of the present by both respondents and analysts. This creates a danger of producing 'Whiggish' biographies which downplay uncertainty, inconsistency, deadends and negative experiences.

Prospective longitudinal data provide a costly but effective method of generating mobility biographies which overcome many of these issues (Taris, 2000). Fortunately, national panel surveys and linked register datasets are increasingly providing a rich seam of prospective data for exploring how mobility is embedded in unfurling life course biographies. This strand of prospective analysis is currently proceeding in two 
promising directions. First, a prominent body of research is exploring how moving decisions evolve over time. By analysing the temporal relationships between dissatisfaction (Diaz-Serrano and Stoyanova, 2010; Rabe and Taylor, 2010), moving desires (Coulter et al., 2011), moving intentions (De Groot et al., 2011; Lu, 1998; Lu, 1999), moving expectations, and actual moving behaviour, these studies are unpacking how moving decisions are situated within subjective as well as objective life course biographies.

Importantly, these studies reveal that people frequently do not behave in accordance with their previously expressed moving desires and intentions (De Groot, 2011; Ferreira and Taylor, 2009). While this may be because life events disrupt decision-making (De Groot et al., 2011), these results also demonstrate how spatiotemporal structures and relational linkages can inhibit individuals from living where they would like to. This draws our attention back to conceptualising residential mobility and immobility as constrained behaviours which both configure and are affected by relationally and biographically linked power geometries (Bailey, 2009). This is highly relevant for public policy, which in Britain often seeks to promote 'choice' in the housing market (DCLG, 2011; ODPM, 2005).

Decision-making studies are increasingly progressing beyond analysing short 'snap-shots' of life courses by using long segments of panel data to explore the patterning of mobility decision-making within and between individuals through time (Coulter and van Ham, 2013). This chimes with developments in contemporary sociology, where researchers are increasingly arguing for trajectory- rather than transition-based analyses (Abbott and Tsay, 2000; Aisenbrey and Fasang, 2010; Pollock, 2007). Adopting a long-term perspective has been facilitated by developments in sequence analysis methods which use algorithms to compute measures of 'similarity' between life courses which can then be grouped, visualised and explored (Aisenbrey and Fasang, 2010; Pollock, 2007). These techniques offer researchers an innovative way to probe questions surrounding the patterning of subjective and objective mobility biographies across cohorts, space and time (Coulter and van Ham, 2013).

A second locus of biographical mobility research has focused upon the spatial dimension of the life course biography (van Ham et al., 2012a). Using different retrospective datasets from the Netherlands, both Blaauboer (2011) and Feijten et al. (2008) have shown that a person's past residential environment predicts their residential choices later in life. For instance, Feijten and colleagues (2008: 157) observe that people who lived in suburbs or rural areas early in life are more likely to move back to these types of places as they get older. In a similar vein, Lundholm (2012) has used Swedish data to reveal that older migrants often move back to the parishes and municipalities where they were born or raised. These studies help us to understand how the contemporary residential mosaic is the outcome of past individual and cohort life course experiences.

An innovative paper by Stovel and Bolan (2004) provides one of the few attempts to study the evolution of residential biographies using prospectively gathered data. Drawing on data from the Panel Study of Income Dynamics, Stovel and Bolan constructed place biographies by tracking the types of settlements sample members had lived in over long periods of their lives. Using algorithmic sequence analysis methods and cluster analysis, the authors isolated several structurally differentiated 'types' of place biographies. 
Stovel and Bolan's paper neatly illustrates the opportunities and challenges facing prospective biographical research into residential mobility and immobility. On the one hand, the proliferation of longitudinal datasets allied with advances in multilevel modelling, sequence analysis and panel modelling techniques provide researchers with an unprecedented arsenal of data and methods. Nonetheless, using these tools to move beyond biographical description towards biographical explanation is tricky (Wu, 2000). Exploring how life course trajectories are intertwined within individuals (Pollock, 2007) and how trajectories are patterned across space-time and across cohorts remains an important and potentially rewarding direction for future biographical research.

\section{New directions in residential mobility theory and analysis}

Innovation in residential mobility research is not solely driven by new datasets, methods or advances in social theory. Instead, it is the interactions between context, theory and analysis that take the field in productive new directions (Findlay, 2003). With this in mind, it becomes clear that contemporary trends, data developments and methodological advances are all interacting to exert pressure on residential mobility theory. In this context there are two theoretical sites which seem especially ripe for conceptual advance.

\section{IV.1 Definitions of residential mobility}

While researchers are well-aware of the complexity of defining what constitutes a residential move (Fielding, 2012: 5), the most commonly used definitions remain rooted in theories developed several decades ago. In particular, Roseman's (1971) definition of mobility as a 'permanent' change in the centre of gravity of daily life continues to hold sway. Yet radical changes in economic, housing and family structures over the last few decades mean that this definition is unable to adequately capture the full range of contemporary experiences. Recent work exploring the impacts of contemporary trends suggests the need to theorise new practices of mobility which disrupt traditional moverstayer dichotomies. For instance, increasing numbers of commuter and 'Live Apart Together' partnerships (van der Klis and Mulder, 2008) as well as high divorce rates and the emergence of complex and reconstituted families (Gram-Hanssen and BechDanielsen, 2008) hint at new forms of residential itinerancy. Rather like seasonal migration (McHugh, 2000), we can think of residential itinerancy as frequent and circular oscillations between multiple residences which each function as temporary centres of gravity.

Longitudinal studies also suggest the emergence of residential transience, particularly amongst young people leaving home, navigating higher education and attempting to enter the labour market (Sage et al., 2013). Residential transience can be defined as occurring when people move in an unstructured fashion between residences (for young adults this often involves using the parental home as a safety net), without having a single centre of gravity (Demey et al, 2011). Taken together, these emerging forms of residential mobility suggest that mobility may be becoming an increasingly diverse and relational practice.

Redefining residential mobility poses methodological challenges and opportunities. While census and administrative data resources like National Health 
Service records or tax returns have been of huge value to mobility researchers (Fielding, 2012; Finney, 2011; Plane and Jurjevich, 2009), these data often only allow people to report living in one place at once. As Sage et al. (2013) show, novel forms of online longitudinal survey can help to circumvent this problem by directly engaging with individuals, thereby allowing insight into the subjective dimensions of relational movements. Given that new forms of residential mobility reinforce the importance of biographically linked lives, large household panel surveys like the UK's Understanding Society also offer exciting possibilities to researchers interested in new forms of mobility behaviour. Sequence analysis techniques challenge researchers to use these subjective longitudinal data to probe how residential moves are not necessarily dramatic life course transitions, but instead may be part and parcel of everyday life.

\section{IV.2 Reconceptualising residential immobility}

Emerging evidence about contemporary processes makes reconceptualising residential immobility a second important locus for research. Contrary to postmodern narratives of 'hyper-mobility', a growing body of American studies show that US migration rates are declining (Cooke, 2011; 2012; Fischer, 2002; Wolf and Longino, 2005). A variety of explanations have been posited to explain this trend. These point to structural economic changes, increased proportions of dual-earner households, the increased ease of longdistance commuting and travel, high rates of homeownership, an ageing population, and the impact of new communications technologies (Cooke, 2011; Kaplan and SchulhoferWohl, 2012). As yet, little progress has been made in disentangling these factors, while it also remains unclear whether migration rates are declining in other countries.

Even if we are unable to completely explain or generalise from declining US migration rates, evidence for reduced American migration nonetheless highlights the need to reconceptualise immobility at both the macro and micro scales. Although demographers have devoted much attention to re-theorising the demographic transition in relation to changing attitudes towards marriage, reproduction and living arrangements (Lesthaege, 1995; van de Kaa, 2004), far less attention has been paid towards rethinking Zelinsky's (1971) notion of a mobility transition (Skeldon, 2012). This contrasts starkly with how international migration research has been enriched over the last two decades by retheorisations around issues of transnationalism and diaspora (Cohen, 2008; Vertovec, 2009).

Evidence from micro-scale research adds impetus to calls for a new theorisation of residential immobility (Cooke, 2011). In keeping with Cresswell's (2012) plea for the new mobilities paradigm to explore stillness and stuckness, so residential mobility research must reconceptualise residential immobility as more than just an absence of movement (Hanson, 2005). This can be achieved using longitudinal data to disentangle the complex meanings of immobility. For instance, linking moving desires to subsequent moving behaviour has allowed Coulter and van Ham (2013) to argue that people can experience multiple forms of immobility. On the one hand, staying in place can be a positive experience characterised by security, location-specific 'insider advantages', rootedness and place attachments (Fischer and Malmberg, 2001). However, immobility can also reflect an inability to act upon a desire to move (Coulter and van Ham, 2013). Residential immobility is therefore a process infused with meaning which is affected by the power imbalances configuring a person's ability to exercise 'choice'. 
Reconceptualising residential immobility is particularly important given the potential impacts of new technologies. As cheaper transportation and new modes of communication allow proximity to be less of a constraint for social interaction and work, we need to rethink how immobility and the reproduction of social and employment ties are recursively linked (Cooke, 2012). Similarly, the role of information in immobility processes also needs to be reconceptualised as information on housing vacancies can now be easily and immediately accessed over the internet (Thulin and Vilhemson, 2013). A longitudinal perspective which engages directly with people to gather data on their daily interactions with others is vital if we are to unpack the links between structural technological changes and cohort-specific trends in residential immobility behaviour.

Importantly, reconceptualising immobility requires adopting a geographical perspective on the evolution of life course biographies. Place must remain a crosscutting theme of any retheorisation of immobility. In a simplistic sense this is because housing values and rents are strongly determined by the attributes of places. Equally, place also configures how technological changes affect experiences of immobility. In a sense, understanding how people use new communications technologies requires consideration of their relational residential biographies. One of the main attractions of innovations like social media and Skype are that these enable people to stay in touch with those they no longer live with or see on a daily basis. Bringing residential biographies into analyses of how people use new technologies may provide a powerful way to demonstrate how past as well as present locations configure social lives across both physical and digital spaces.

In summary, empirical evidence as well as developments in data resources and analytical techniques suggest that the time is ripe for geographers to reconceptualise both residential mobility and immobility. While new data and methods allow researchers to analyse the significance of space-time relations in new ways, empirical analyses also reveal how residential mobility theory has not kept pace with demographic, economic and technological change.

\section{New contexts, new agendas?}

While contextual change can stimulate theoretical and analytical innovation, new contexts also shape the questions we ask about how residential mobility and immobility are implicated in the structuration of societies. As Philo (2001: 486) notes, the 'real worldly population geography beyond the academy' therefore demands our attention (Findlay, 2003). Critical engagement with contemporary issues is also important because our answers to the questions posed by policymakers, the media or the public can, and perhaps should, have 'real worldly' consequences (Hamnett, 2011).

With this in mind, this section argues that a revitalised residential mobility research agenda must grapple with two contemporary challenges: namely the impact of the Global Economic Crisis (GEC) and austerity politics (Hamnett, 2011), as well as the social changes associated with demographic restructuring (Berrington et al., 2009; Demey et al., 2011). Both of these issues are bringing discussion of mobility patterns and behaviours to the forefront of academic and public debate. Understanding, critiquing and addressing the challenges posed by the GEC and demographic change 
therefore necessitates taking residential mobility research in new substantive, theoretical and analytical directions.

\section{V.1 The impacts of the Global Economic Crisis and austerity politics}

Given that the GEC was triggered by a financial crisis generated in the housing system, it is perhaps surprising that so few geographers have as yet engaged with how the GEC is reshaping the geographies of mobility. While some researchers have probed the effects of recession on international migration (Findlay et al., 2010), very few have focused on internal migration (Cooke, 2011; 2012; Fielding, 2012) or residential mobility (Ferreira et al., 2010). Nonetheless, the austerity policies many countries have adopted over the last few years should be placing poststructural notions of the uneven geography of power relations at the heart of residential mobility and immobility research. The crisis reminds us that residential mobility is not simply a decontextualized process matching people to dwellings (Clark et al., 2006). Instead, unequal access to resources and questions of power condition how residential mobility and immobility act as engines of social structuration.

The GEC and austerity politics pose two new sets of research questions about residential mobility and immobility that can only be addressed by considering issues of relationality, biography and power. Firstly, contextual changes linked to the GEC guide us to probe the impacts of unwanted residential (im)mobility on people's material, cultural and psychological wellbeing (Fielding, 1992). In the UK, the GEC may on the one hand be inhibiting people from making desired moves. This is because pay freezes, benefit reductions and the rising cost of living are reducing household resources, while high (but geographically polarised) rent levels and constrained access to homeownership create an often insurmountable barrier to moving. At the same time, welfare reforms such as Housing Benefit caps and the controversial 'spare bedroom tax' are likely to force poor households and social tenants to make unwanted residential moves (Hamnett, 2011). Given debates about neighbourhood effects (van Ham et al., 2012b) and evidence that acting upon moving desires is linked to improved well-being (Nowok et al., 2013), biographical research can help us to understand how structural constraints mould prosperity and well-being over the life course. This is important for reconceptualising residential mobility and immobility as heterogeneous processes which can be either a choice or the outcome of a lack of choice.

These issues suggest that exploring the normative politics of residential mobility and immobility is a second important direction for research. By highlighting how power flows through discourse, poststructural theories allow us to identify and critique how state actors propagate a normative view of mobility which constructs the (non)movements of particular groups as the cause of social ills (Imbroscio, 2012). These discursive constructions are then used to legitimate particular policies. For example in the UK, the immobility of social tenants with spare rooms or households claiming high levels of Housing Benefit is constructed as a problem which justifies restructuring the welfare system to stimulate particular forms of mobility. These discursive constructions of deviant (im)mobilities intersect with issues of relationality, for example as policies to restrict Housing Benefit for young adults draw on and reproduce age-norms about the type of living arrangements people should be prepared to accept. Theorisation and analysis of the power politics of mobility can therefore be enhanced by insights from the life course perspective, most notably through a focus on 
how power structures draw on and reconfigure relational and biographical norms about residential mobility behaviour and household structures.

\section{V.2 Residential mobility, immobility and demographic change}

While the GEC highlights the importance of incorporating questions of power relations into the study of residential mobility and immobility, contemporary demographic trends guide researchers to investigate how relocation behaviour is linked to reciprocal exchanges and cohort patterns in biographies. As population distribution configures the geography of demand for services and infrastructure (Bell and Rutherford, 2013; Rees et al., 2013), it is vital for population geographers to link residential mobility and immobility to demographic trends such as population ageing (Evandrou et al, 2010), growing ethnic diversity (Simpson and Finney, 2009), and increasingly varied and complex family structures and domestic living arrangements (Berrington et al., 2009; Demey et al., 2011).

Demographic change is driving residential mobility research in two interlinked directions. As the need to respond to population ageing and the spiralling cost of childcare rises up the political agenda, questioning how residential mobility and immobility are embedded in intergenerational exchanges of care is becoming a key locus for research (Falkingham et al., 2010; Swartz, 2009). As care and support can often only be provided through direct contact, understanding when and how care needs influence residential mobility is an important goal for policy-driven research as well as theorisations of how lives are linked across space-time (Mulder, 2007; Pettersson and Malmberg, 2009). Given that the groups most implicated in intergenerational exchanges of care (such as families and the elderly) relocate only infrequently, longitudinal perspectives on the 'family adaptive strategies' mobilised in place by those needing or providing care are equally important for retheorising residential immobility (Lundholm and Malmberg, 2010; Moen and Wethington, 1992). As welfare retreat and social inequalities mean that some groups are more reliant on familial networks of care than others (Swartz, 2009), there is a clear need to build power relations into our understanding of how residential mobility structures, and is influenced by, relational practices of caring.

Secondly, the changing volume and geography of international migration flows over time suggests that linked longitudinal analyses of migration and residential mobility can help us to understand the future geographies of ethnicity (Ellis, 2012). As personal ties and collective memories influence residential preferences (Sharkey, 2012), tracking the movements of cohorts of immigrants and their descendants can help us to understand how ethnic patterns of mobility behaviour change over time. This is important for both businesses and policymakers, as ethnic geographies affect the demand for shops and services as well as patterns of segregation (Rees et al., 2013; Simpson and Finney, 2009). Fortunately, such work is becoming increasingly practical with the advent of population-scale longitudinal datasets tracking people over long periods of time ${ }^{3}$. Using these resources to conduct residential mobility research which makes links to global systems and the changing patterns of cohort experience promises to greatly enhance our understanding of how mobility and ethnicity are intertwined across space-time. 


\section{Conclusions}

This paper has argued that even in a world of transnational families, international migration and new forms of mobility, understanding the geographies of residential mobility and immobility remains of crucial importance. Appreciating how mobility is embedded within everyday lives of production and reproduction requires a focus on short-distance moves and periods of immobility. If residential mobility and immobility recursively link people and places, then understanding local moves and residential stability is critical for conceptualising agency-structure relations as they vary over time and space. This has only recently become possible with the arrival of high quality georeferenced longitudinal datasets. These not only allow analysts to operationalize the key tenets of social theory. Importantly, novel data and methods also enable geographers to use empirical evidence to identify where social changes are creating a need for new theorisations.

Residential mobility and immobility are important because they (re)produce spatial and temporal inequalities. Processes of neighbourhood stratification, segregation and gentrification are all configured by mobility and immobility patterns (Clark, 2008), while intergenerational exchanges of care, wealth and resources depend upon relational mobility biographies (Mulder, 2007). While recent reviews have argued that longdistance migration produces spatial inequalities (Smith, 2011), we must not forget that local moves and residential (im)mobility play equally important roles in these processes.

A revitalised residential mobility research agenda is also required to respond to the challenges posed by the GEC and contemporary demographic trends. Questions about mobility and immobility are a fundamental component of how we conceptualise and respond to these issues. Analysing how residential mobility is embedded in these new contexts will therefore help us to produce 'real worldly population geographies' (Philo, 2001: 486) which can have impacts beyond the academy.

To achieve these aims requires taking residential mobility research in the new directions suggested by the interplay of contextual change, analytical advances and theoretical innovation. As this review has shown, the growing influence of life course theories has drawn attention to how lives are linked over space and time (Bailey, 2009). Emerging from this literature is a general reconceptualization of mobility as a situated process which unfolds over time (Kley and Mulder, 2010). This reconceptualization has, in turn, stimulated an explosion of interest in what quantitative longitudinal analyses can reveal (Mayer, 2009).

Empirical research making use of new longitudinal data and methods is combining with contextual changes to challenge existing theories of residential mobility and immobility. Using long periods of panel data and sequence analysis methods shows us that residential immobility is a heterogeneous state which can be the product of choice or constraints (Hanson, 2005). Equally, contextual changes towards more diverse and complex family structures suggest a focus on new forms of residential mobility which are poorly captured in census or administrative data resources (Sage et al., 2013). Taken together, these developments suggest that residential mobility and immobility are diverse processes which are ripe for retheorisation.

Extending these new directions is important for producing both policy-directed and policy-critical knowledge. Infusing life course notions of relationality and cohort change with ideas of reciprocity and exchange is vital for engaging with the challenges 
produced by demographic trends and welfare retrenchment (Michielin et al., 2008; Pettersson and Malmberg, 2009). Perhaps more importantly, rethinking residential mobility and immobility in the context of the GEC and austerity politics requires researchers to pay greater attention to issues of inequality and power relations (Bailey, 2009). While there is a long tradition of scholarship investigating how power flows through migration to (re)produce spatial (Smith, 2011), gendered (Halfacree, 1995; Smith, 2004) and class inequities (Fielding, 2012), recent policy initiatives and housing market problems challenge us to extend these concerns into residential mobility research. This calls for a focus on the subjective dimensions of (not) moving which recognises that mobility and immobility are heterogeneous processes with diverse meanings and implications (Nowok et al., 2013). Moreover, since life course theories argue that cohort experiences can have long-lasting effects, there is a clear need to remain aware of how inequities (re)produced by residential mobility at one point in the life course could have significant impacts on later life course outcomes in fields as diverse as living arrangements, family relations and wealth accumulation (Gayle et al., 2008; Hillmert, 2013).

Tracing these new directions requires moving beyond the empirical orientation of much existing residential mobility research to build stronger links with social theories. While residential mobility research would benefit from drawing on poststructural theories, other subfields of human geography could be enriched by harnessing the longitudinal emphasis on contextualising change over time that is becoming a key theme in studies of residential mobility. Overall, re-contouring the outcomes of residential moves and rethinking the meanings of residential mobility and immobility opens up promising new directions for geographical scholarship.

\section{Acknowledgements}

Part of this research was financially supported by the EU (NBHCHOICE Career Integration Grant under FP7-PEOPLE-2011-CIG).

\footnotetext{
Notes

${ }^{1}$ Note however Bakewell's (2010) critique of whether agency-structure relations can ever be adequately conceptualised using Gidden's original formulation of structuration theory. In this paper structuration is used somewhat broadly to mean that agents and structures are recursively linked. The actions of agents (re)produce social structures, which in turn influence social practice.

${ }^{2}$ Retrospective longitudinal data are data gathered about past attributes at a single point in time. For example, a retrospective study might build up residential biographies by interviewing people about their residential histories. In contrast, prospective longitudinal data are collected by repeatedly gathering data from research units (such as people, firms or countries) as they move through time (Taris, 2000). A prospective study might therefore generate residential biographies by repeatedly surveying a panel of respondents.

${ }^{3}$ Examples include the ONS Longitudinal Study of England and Wales, or population registers in Denmark, the Netherlands and Sweden.
} 


\section{References}

Abbott A and Tsay A (2000) Sequence analysis and optimal matching methods in sociology: Review and prospect. Sociological Methods \& Research 29: 3-33.

Abraham M, Auspurg K and Hinz T (2010) Migration decisions within dual-earner partnerships: A test of bargaining theory. Journal of Marriage and Family 72: 876-892.

Adey P (2010) Mobility. London: Routledge.

Aisenbrey S and Fasang AE (2010) New life for old ideas: The "second wave" of sequence analysis bringing the "course" back into the life course. Sociological Methods \& Research 38: 420-462.

Bailey AJ (2009) Population geography: Lifecourse matters. Progress in Human Geography 33: 407-418.

Bailey AJ, Blake MK and Cooke TJ (2004) Migration, care, and the linked lives of dual-earner households. Environment and Planning A 36: 1617-1632.

Bailey N and Livingston M (2007) Population Turnover and Area Deprivation. A report for the Joseph Rowntree Foundation. Bristol: Policy Press.

Bakewell O (2010) Some reflections on structure and agency in migration theory. Journal of Ethnic and Migration Studies 36: 1689-1708.

Battu H, Gerova V and Phimister E (2005) Residential mobility. In: Ermisch JF and Wright RE (eds) Changing Scotland: Evidence from the British Household Panel Survey. Bristol: Policy Press, 63-81.

Bell D and Rutherford A (2013) The geography of care networks. Population Space and Place Early View: DOI:10.1002/psp.1792.

Belot M and Ermisch J (2009) Friendship ties and geographical mobility: Evidence from Great Britain. Journal of the Royal Statistical Society: Series A 172: 427442.

Berrington A, Stone J and Falkingham J (2009) The changing living arrangements of young adults in the UK. Population Trends 138: 27-37.

Blaauboer M (2011) The impact of childhood experiences and family members outside the household on residential environment choices. Urban Studies 48: 1635-1650.

Blaauboer M, Strömgren M and Stjernström O (2013) Life course preferences, sibling ties, and the geographical dispersion of sibling networks. Population, Space and Place 19: 594-609.

Blunt A (2007) Cultural geographies of migration. Progress in Human Geography 31: 684-94.

Brown LA and Moore EG (1970) The intra-urban migration process: A perspective. Geografiska Annaler, Series B 52: 1-13.

Bushin N (2009) Researching family migration decision- making: A children-infamilies approach. Population, Space and Place 15: 429-443.

Carling J (2007) Transnationalism in the context of restrictive immigration policy. $\mathrm{PhD}$ thesis, University of Oslo.

Carling J, Schmalzbauer L and Menjívar C (2012) Central themes in the study of transnational parenthood. Journal of Ethnic and Migration Studies 38: 191-217.

Clark A (2009) Moving through deprived neighbourhoods. Population, Space and Place 15: 523-533.

Clark WAV (2008) Geography, space, and science: Perspectives from studies of migration and geographical sorting. Geographical Analysis 40: 258-275. 
Clark WAV and Davies Withers S (2007) Family migration and mobility sequences in the United States. Demographic Research 17: 591-622.

Clark WAV, Deurloo M and Dieleman F (2006) Residential mobility and neighbourhood outcomes. Housing Studies 21: 323-342.

Clark WAV and Huang Y (2003) The life course and residential mobility in British housing markets. Environment and Planning A 35: 323-339.

Clark WAV and Huang Y (2004) Linking migration and mobility: Individual and contextual effects in housing markets in the UK. Regional Studies 38: 617-628.

Clark WAV and Ledwith V (2006) Mobility, housing stress, and neighborhood contexts: Evidence from Los Angeles. Environment and Planning A 38: 10771093.

Clark WAV and Maas R (2012) Interpreting migration through the prism of reasons for moves: What can we learn about the economic returns to migration from survey data? California Center for Population Research Online Working Paper Series PWP-CCPR-2012-017. Los Angeles: University of California at Los Angeles. Available at: papers.ccpr.ucla.edu/download.php?paper=PWP-CCPR-2012-017 (accessed 23/04/13).

Cohen R (2008) Global Diasporas. Routledge: London.

Cooke TJ (2008) Migration in a family way. Population, Space and Place 14: 255-265.

Cooke TJ (2011) It is not just the economy: Declining migration and the rise of secular rootedness. Population, Space and Place 17: 193-203.

Cooke TJ (2012) Internal migration in decline. The Professional Geographer Early View: DOI:10.1080/00330124.2012.724343.

Coulson NE and Fisher LM (2009) Housing tenure and labor market impacts: The search goes on. Journal of Urban Economics 65: 252-264.

Coulter R, van Ham M and Feijten P (2011) A longitudinal analysis of moving desires, expectations and actual moving behaviour. Environment and Planning A 43: 2742-2760.

Coulter R, van Ham M and Feijten P (2012) Partner (dis)agreement on moving desires and the subsequent moving behaviour of couples. Population, Space and Place 18: $16-30$.

Coulter R and van Ham M (2013) Following people through time: An analysis of individual residential mobility biographies. Housing Studies OnlineFirst: DOI:0.1080/02673037.2013.783903.

Cresswell T (2011) Mobilities I: Catching up. Progress in Human Geography. 35: 550558.

Cresswell T (2012) Mobilities II: Still. Progress in Human Geography 36: 645-653.

De Groot C (2011) Longitudinal analysis. In: Jansen SJT, Coolen H and Goetgeluk RW (eds) The Measurement and Analysis of Housing Preference and Choice. London: Springer, 225-252.

De Groot C, Mulder CH, Das M and Manting D (2011) Life events and the gap between intention to move and actual mobility. Environment and Planning A 43: 48-66.

Demey D, Berrington A, Evandrou M and Falkingham J (2011) The changing demography of mid-life, from the 1980s to the 2000s. Population Trends 145: 1634.

Dennett A and Stillwell J (2010) Internal migration in Britain, 2000-01, examined through an area classification framework. Population, Space and Place 16: 517538. 
Department for Communities and Local Government (DCLG) (2011) Laying the Foundations: A Housing Strategy for England. London: Department for Communities and Local Government.

Diaz-Serrano L and Stoyanova AP (2010) Mobility and housing satisfaction: An empirical analysis for 12 EU countries. Journal of Economic Geography 10: 661683.

Dykstra P and van Wissen L (1999) Introduction: The life course approach as an interdisciplinary framework for population studies. In: van Wissen L and Dykstra P (eds) Population Issues: An Interdisciplinary Focus. New York: Plenum Press, $1-22$.

Elder GH (1994) Time, human agency, and social change: Perspectives on the life course. Social Psychology Quarterly 57: 4-15.

Ellis M (2012) Reinventing US internal migration studies in the age of international migration. Population, Space and Place 18: 196-208.

Evandrou M, Falkingham J and Green M (2010) Migration in later life: Evidence from the British Household Panel Study. Population Trends 141: 77-94.

Falkingham J, Evandrou M and Vlachantoni A (2010) Gender, poverty and pensions in the UK. In: Chant S (ed.) International Handbook on Gender and Poverty. Cheltenham: Edward Elgar, 232-237.

Feijten P (2005) Life Events and the Housing Career: A Retrospective Analysis of Timed Effects. Delft: Eburon.

Feijten P, Hooimeijer P and Mulder CH (2008) Residential experience and residential environment choice over the life-course. Urban Studies 45: 141-162.

Feijten P and van Ham M (2013) The consequences of divorce and splitting up for spatial mobility in the UK. Comparative Population Studies 38: 405-432.

Ferreira F, Gyourko J and Tracy J (2010) Housing busts and household mobility. Journal of Urban Economics 68: 34-45.

Ferreira P and Taylor MP (2009) Residential mobility, mobility preferences and psychological health. In: Brynin M and Ermisch J (eds) Changing Relationships. Oxford: Routledge, 161-189.

Fielding $\mathrm{T}$ (1992) Migration and culture. In: Champion $\mathrm{T}$ and Fielding $\mathrm{T}$ (eds) Migration Processes and Patterns Volume 1: Research Progress and Prospects. London: Belhaven Press, 201-212.

Fielding (2012) Migration in Britain: Paradoxes of the Present, Prospects for the Future. Cheltenham: Edward Elgar.

Findlay AM (2003) Population geographies for the 21st century. Scottish Geographical Journal 119: 177-190.

Findlay AM, Geddes A and McCollum D (2010) International migration and recession. Scottish Geographical Journal 126: 299-320.

Findlay AM and Li FLN (1997) An auto-biographical approach to understanding migration: The case of Hong Kong emigrants. Area 29: 34-44.

Finney N (2011) Understanding ethnic differences in the migration of young adults within Britain from a lifecourse perspective. Transactions of the Institute of British Geographers 36: 455-470.

Fischer CS (2002) Ever-more rooted Americans. City \& Community 1: 177-198.

Fischer PA and Malmberg G (2001) Settled people don't move: On life course and (im)mobility in Sweden. International Journal of Population Geography 7: 357-371. 
Friedman S (2011) Bringing proximate neighbours into the study of US residential segregation. Urban Studies 48: 611-639.

Gayle V, Boyle P, Flowerdew R and Cullis A (2008) Family migration and social stratification. International Journal of Sociology and Social Policy 28: 293-303.

Geist C and McManus P (2008) Geographical mobility over the life course: Motivations and implications. Population, Space and Place 14: 283-303.

Geist C and McManus P (2012) Different reasons, different results: Implications of migration by gender and family status. Demography 49: 197-217.

Graham E, Findlay AM, Manley DJ, McCollum D, Popham F and van Ham M (2011) Scotland's census as a research resource. In: General Registrar Office for Scotland (ed.) Scotland's Population 2010: The Registrar General's Annual Review of Demographic Trends. National Records for Scotland: Edinburgh, 73-87.

Gram-Hanssen K and Bech-Danielsen C (2008) Home dissolution: What happens after separation? Housing Studies 23: 507-522.

Gutting D (1996) Narrative identity and residential history. Area 28: 482-490.

Halfacree KH (1995) Household migration and the structuration of patriarchy: evidence from the USA. Progress in Human Geography 19: 159-182.

Halfacree K (2004) A utopian imagination in migration's terra incognita? Acknowledging the non-economic worlds of migration decision-making. Population, Space and Place 10: 239-253.

Halfacree KH and Boyle PJ (1993) The challenge facing migration research: the case for a biographical approach. Progress in Human Geography 17: 333-348.

Hamnett C (2011) The reshaping of the British welfare system and its implications for geography and geographers. Progress in Human Geography 35: 147-152.

Hanson S (2005) Perspectives on the geographic stability and mobility of people in cities. Proceedings of the National Academy of Sciences 102: 15301-15306.

Healey, R. L. (2006) Asylum seekers and refugees: A structuration theory analysis of their experiences in the UK. Population, Space and Place 12: 257-271.

Heath S and Calvert E (2013) Gifts, loans and intergenerational support for young adults. Sociology Early View: DOI:10.1177/0038038512455736.

Hedin K, Clark E, Lundholm E and Malmberg G (2012) Neoliberalization of housing in Sweden: Gentrification, filtering, and social polarization. Annals of the Association of American Geographers 102: 443-463.

Hedman L (2013) Moving near family? The influence of extended family on neighbourhood choice in an intra-urban context. Population, Space and Place 19: 32-45.

Hedman L, van Ham M and Manley D (2011) Neighbourhood choice and neighbourhood reproduction. Environment and Planning A 43: 1381-1399.

Helderman A and Mulder C (2007) Intergenerational transmission of homeownership: The roles of gifts and continuities in housing market characteristics. Urban Studies 44: 231-247.

Hillmert S (2013) Analysing intergenerational transmissions: From social mobility to social reproduction. In: Birkelund GE (ed.) Class and Stratification Analysis. Bingley: Emerald Group Publishing Limited, pp. 131-158.

Holdsworth C (2013) Families and Intimate Mobilities. Basingstoke: Palgrave Macmillan.

Imbroscio D (2012) Beyond mobility: The limits of liberal urban policy. Journal of Urban Affairs 34: 1-20. 
Kaplan G and Schulhofer-Wohl S (2012) Understanding the long-run decline in interstate migration. National Bureau of Economic Research Working Paper 18507. Cambridge MA: National Bureau of Economic Research. Available at: http://www.nber.org/papers/w18507.pdf (accessed 17/07/13).

Kley S (2011) Explaining the stages of migration within a life-course framework. European Sociological Review 27: 469-486.

Kley SA and Mulder CH (2010) Considering, planning, and realizing migration in early adulthood. The influence of life-course events and perceived opportunities on leaving the city in Germany. Journal of Housing and the Built Environment 25: 73-94.

King R (2012) Geography and migration studies: Retrospect and prospect. Population, Space and Place 18: 134-153.

Kulu H and Boyle P (2010) Pre-marital co-habitation and divorce: Support for the "trial marriage" theory? Demographic Research 23: 879-904.

Kurz K (2004) Labour market position, intergenerational transfers and homeownership: A longitudinal analysis for West German birth cohorts. European Sociological Review 20: 141-159.

Lesthaege R (1995) The second demographic transition in Western countries. In: Mason $\mathrm{K}$ and Jensen A (eds) Gender and Family Change in Industrialised Countries. Oxford: Oxford University Press, 17-27.

Lu M (1998) Analyzing migration decisionmaking: Relationships between residential satisfaction, mobility intentions, and moving behavior. Environment and Planning A 30: 1473-1495.

Lu M (1999) Do people move when they say they will? Inconsistencies in individual migration behavior. Population \& Environment 20: 467-488.

Lundholm E (2012) Returning home? Migration to birthplace among migrants after age 55. Population, Space and Place 18: 74-84.

Lundholm E and Malmberg G (2010) Between elderly parents and grandchildren: Geographic proximity and trends in four-generation families. Journal of Population Ageing 2: 121-137.

McHugh KE (2000) Inside, outside, upside down, backward, forward, round and round: A case for ethnographic studies in migration. Progress in Human Geography 24: 71-89.

Mason J (2004) Personal narratives, relational selves: Residential histories in the living and telling. The Sociological Review 52: 162-179.

Mayer KU (2009) New directions in life course research. Annual Review of Sociology 35: 413-433.

Michielin F, Mulder CH and Zorlu A (2008) Distance to parents and geographical mobility. Population, Space and Place 14: 327-345.

Mitchell K (2004) Geographies of identities: Multiculturalism unplugged. Progress in Human Geography 28: 641-651.

Moen P and Wethington E (1992) The concept of family adaptive strategies. Annual Review of Sociology 18: 233-251.

Mulder CH (2007) The family context and residential choice: A challenge for new research. Population, Space and Place 13: 265-278.

Mulder CH and Cooke TJ (2009) Family ties and residential locations. Population, Space and Place 15: 299-304. 
Mulder CH and Hooimeijer P (1999) Residential relocations in the life course. In: van Wissen L and Dykstra P (eds) Population Issues: An Interdisciplinary Focus. New York: Kluwer Academic/Plenum Publishers, 159-186.

Mulder CH and Malmberg G (2011) Moving related to separation: Who moves and to what distance. Environment and Planning A 43: 2589-2607.

Mulder $\mathrm{CH}$ and Wagner M (2010) Union dissolution and mobility: Who moves from the family home after separation? Journal of Marriage and Family 72: 12631273.

Nowok B, van Ham M, Findlay A and Gayle V (2013) Does migration make you happy? A longitudinal study of internal migration and subjective well-being. Environment and Planning A 45: 986-1002.

Office of the Deputy Prime Minister (ODPM) (2005) Sustainable Communities: Homes for All: A Five Year Plan from the Office of the Deputy Prime Minister. Norwich: HMSO.

Pettersson A and Malmberg G (2009) Adult children and elderly parents as mobility attractions in Sweden. Population, Space and Place 15: 343-357.

Philo C (2001) Accumulation populations. International Journal of Population Geography 7: 473-490.

Plane DA and Jurjevich JR (2009) Ties that no longer bind? The patterns and repercussions of age-articulated migration. The Professional Geographer 61: 420.

Pollock G (2007) Holistic trajectories: A study of combined employment, housing and family careers by using multiple-sequence analysis. Journal of the Royal Statistical Society: Series A 170: 167-183.

Rabe B (2012) Moving home: Wishes, expectations, and reasons. In: McFall SL (ed.) Understanding Society: Findings 2012. Colchester: Institute for Social and Economic Research, University of Essex, 17-18.

Rabe B and Taylor M (2010) Residential mobility, quality of neighbourhood and life course events. Journal of the Royal Statistical Society: Series A 173: 531-555.

Rees P, Wohland P and Norman P (2013) The demographic drivers of future ethnic group populations for UK local areas 2001-2051. The Geographical Journal 179: 44-60.

Roseman CC (1971) Migration as a spatial and temporal process. Annals of the Association of American Geographers 61: 589-598.

Rossi PH (1955) Why Families Move: A Study in the Social Psychology of Urban Residential Mobility. Glencoe, IL: Free Press.

Sage J, Evandrou M and Falkingham J (2013) Onwards or homewards? Complex graduate migration pathways, well-being, and the 'parental safety net'. Population, Space and Place Early View: DOI:10.1002/psp1793.

Schwartz N (2012) Why researchers should think "real-time": A cognitive rationale. In: Mehl M and Conner T (eds) Handbook of Research Methods for Studying Daily Life. New York: Guildford Press, 22-42.

Scott J (1997) Changing households in Britain: Do families still matter? The Sociological Review 45: 591-620.

Seavers J (1999) Residential relocation of couples: The joint decision-making process considered. In: Boyle P and Halfacree KH (eds) Migration and Gender in the Developed World. London: Routledge, 151-171. 
Sharkey P (2012) Residential mobility and the reproduction of unequal neighborhoods. Cityscape: A Journal of Policy Development and Research 14: 9-32.

Sheller M and Urry J (2006) The new mobilities paradigm. Environment and Planning A 38: 207-226.

Simpson L and Finney N (2009) Spatial patterns of internal migration: Evidence for ethnic groups in Britain. Population, Space and Place 15: 37-56.

Skeldon R (2012) Migration transitions revisited. Population, Space and Place 18: 15466.

Smart C (2011) Relationality and socio-cultural theories of family life. In: Jallinoja R and Widmer ED (eds) Families and Kinship in Contemporary Europe: Rules and Practices of Relatedness. Basingstoke: Palgrave Macmillan, 13-28.

Smith DP (2004) An "untied" research agenda for family migration: Loosening the "shackles" of the past. Journal of Ethnic and Migration Studies 30: 263-282.

Smith DP (2008) The politics of studentification and '(un)balanced' urban populations: Lessons for gentrification and sustainable communities? Urban Studies 45: 25412564.

Smith DP (2011) Geographies of long-distance family migration: Moving to a "spatial turn”. Progress in Human Geography 35: 652-668.

Smith DP and King R (2012) Editorial introduction: Re-making migration theory. Population, Space and Place 18: 127-133.

Speare A Goldstein S and Frey WH (1975) Residential Mobility, Migration and Metropolitan Change. Cambridge MA: Ballinger.

Stone J, Berrington A and Falkingham J (2011) The changing determinants of young adults' living arrangements. Demographic Research 25: 629-666.

Stovel K and Bolan M (2004) Residential trajectories: Using optimal alignment to reveal the structure of residential mobility. Sociological Methods \& Research 32: 559-598.

Swartz TT (2009) Intergenerational family relations in adulthood: Patterns, variations, and implications in the contemporary United States. Annual Review of Sociology 35: 191-212.

Taris, T (2000) A Primer in Longitudinal Data Analysis. SAGE: London.

Thulin E and Vilhemson B (2013) Virtual practices and migration plans: A qualitative study of urban young adults. Population, Space and Place Early View: DOI:10.1002/psp.1766.

van de Kaa D (2004) Is the second demographic transition a useful research concept? Vienna Yearbook of Population Research 2: 4-10.

van der Klis M and Mulder CH (2008) Beyond the trailing spouse: The commuter partnership as an alternative to family migration. Journal of Housing and the Built Environment 23: 1-19.

van Ham M, Hedman L, Manley D, Coulter R and Östh J (2012a) Intergenerational transmission of neighbourhood poverty in Sweden: An innovative analysis of individual neighbourhood histories. IZA Discussion Paper 6572. IZA: Bonn. Available at: http://www.iza.org/en/webcontent/publications/papers/viewAbstract?dp_id=6572 (accessed 25/04/13).

van Ham M, Manley D, Bailey N, Simpson L and Maclennan D (eds) (2012b) Neighbourhood Effects Research: New Perspectives. Dordrecht: Springer.

Vertovec S (2009) Transnationalism. London: Routledge. 
Warnes T (1992) Migration and the life course. In: Champion T and Fielding T (eds) Migration Processes and Patterns Volume 1: Research Progress and Prospects. London: Belhaven Press, 175-187.

Winstanley A, Thorns D and Perkins H (2002) Moving house, creating home: Exploring residential mobility. Housing Studies 17: 813-832.

Wolf DA and Longino CF (2005) Our "increasingly mobile society”? The curious persistence of a false belief. The Gerontologist 45: 5-11.

Wu LL (2000) Some comments on "Sequence analysis and optimal matching methods in sociology: Review and prospect”. Sociological Methods \& Research 29: 41-64.

Yeoh B, Huang S and Lam T (2005) Transnationalizing the 'Asian' family. Global Networks 5: 307-315.

Zelinsky W (1971) The hypothesis of the mobility transition. Geographical Review 61: 219-249. 